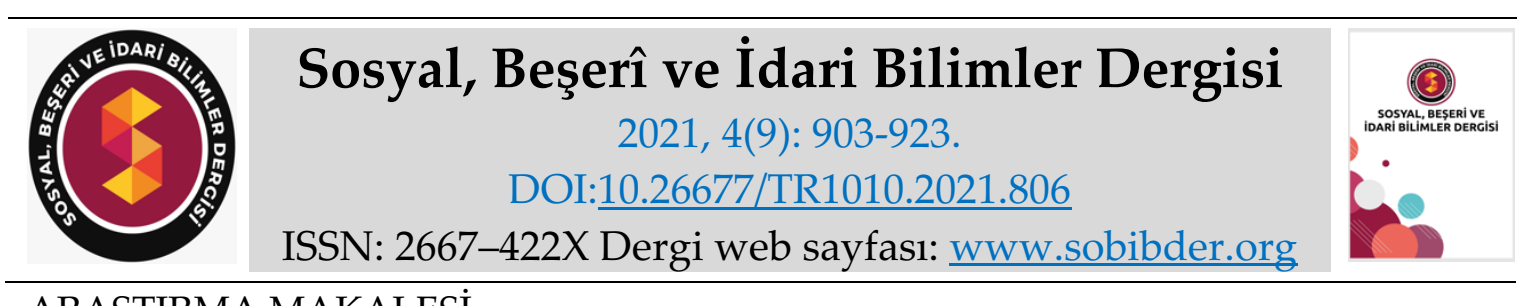

ARASTIRMA MAKALESI

\title{
Dijital Ortamda Kurumsal Sosyal Sorumluluk Faaliyetlerinin Sunumu: Sabancı Vakfı ve Vehbi Koç Vakfı
}

Prof. Dr. Gülcan IŞIK, Ankara Hacı Bayram Veli Üniversitesi, İletişim Fakültesi, Ankara, eposta: gulcankarakaya@gmail.com

ORCID: https://orcid.org/0000-0002-6296-7802

Yunus Emre TOPRAK, Doktora Öğrencisi, Gazi Üniversitesi, Sosyal Bilimler Enstitüsü, Ankara, e-posta: emretoprak0633@gmail.com

ORCID: https://orcid.org/0000-0002-7251-9376

Öz

Kurumsal sosyal sorumluluk en önemli kurumsal itibar bileşenlerinden birisidir. Günümüzde şirketler kurumsal itibarların korumak ve arttırmak amaciyla kurumsal sosyal sorumluluk projelerine giderek artan bir şekilde önem vermektedirler. Şirketler içinde yer aldıkları projeleri kamuoyuna duyurarak toplum ve paydaşların gözünde itibarlarını sürdürmek ve arttırmak istemektedirler. Bu bağlamda, internet erişimindeki artış ve sosyal medya platformlarının bireyler tarafından yoğun bir şekilde kullanımıyla, kurumsal web siteleri ve sosyal medya platformları şirketlerin kurumsal sosyal sorumluluk projelerini topluma ve paydaşlarına tanıtmasında önemli araçlar haline gelmiştir. Çalışmada kurumsal sosyal sorumluluk faaliyetlerinin gelişen iletişim teknolojileri kapsamında kamuoyuna sunuluş biçimlerine odaklanılmıştır. Ülkemizin en önemli şirket gruplarından ikisi olan Sabancı Holding ve Koç Holding kurumsal sosyal sorumluluk faaliyetlerini Sabancı Vakfı ve Vehbi Koç Vakfı üzerinden yürütmektedirler. Bu bağlamda, Sabancı Vakfı ve Vehbi Koç Vakfı'nın web sitesi içerikleri ve 1 Mart 2021-1 Haziran 2021 tarihleri arasında Facebook sosyal medya hesapları üzerinden yaptıkları paylaşımlar nitel ve nicel içerik analizi yöntemi ile incelenmiştir.

Anahtar Kelimeler: Kurumsal İtibar, Kurumsal Sosyal Sorumluluk, İnternet, Sosyal Medya, Facebook, Sabancı Vakfı, Vehbi Koç Vakfı.

Makale Gönderme Tarihi: 28.05.2021

Makale Kabul Tarihi: 01.09.2021

\section{Önerilen Atıf:}

Işık, G. ve Toprak, Y. E. (2021). Dijital Ortamda Kurumsal Sosyal Sorumluluk Faaliyetlerinin Sunumu: Sabancı Vakfı ve Vehbi Koç Vakfı, Sosyal, Beşeri ve İdari Bilimler Dergisi, 4(9): 903-923. (C) 2021 Sosyal, Beşerî ve İdari Bilimler Dergisi. 


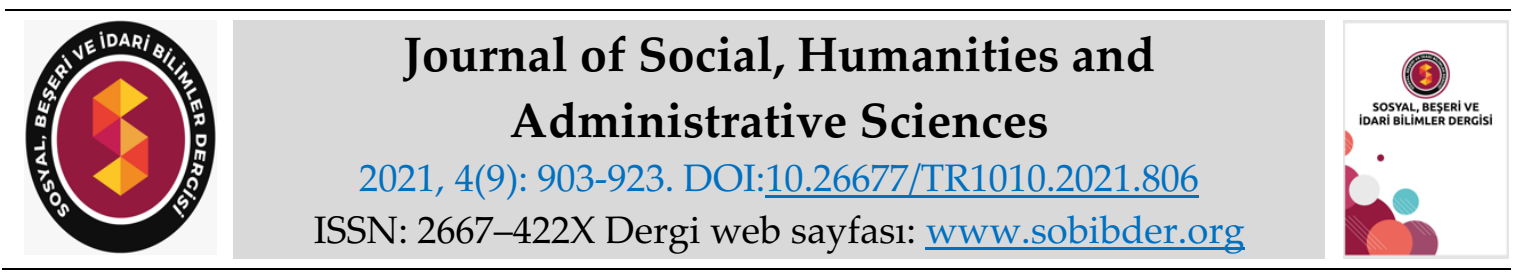

RESEARCH PAPER

\title{
Presentation of Corporate Social Responsibility Actions in Digital Environment: Sabancı Foundation and Vehbi Koç Foundation
}

Prof. Dr. Gülcan IŞIK, Ankara Hacı Bayram Veli University, Faculty of Communication, Ankara, e-mail: gulcankarakaya@gmail.com

ORCID: https://orcid.org/0000-0002-6296-7802

Yunus Emre TOPRAK, Ph.D. Student, Gazi University, Institute of Social Sciences, Ankara, email: emretoprak0633@gmail.com

ORCID: https://orcid.org/0000-0002-7251-9376

\begin{abstract}
Corporate social responsibility is one of the most important components of corporate reputation. Nowadays, organizations increasingly take notice of corporate social responsibility projects so as to keep and increase their corporate reputations. Organizations want to maintain and raise their reputation in the estimation of society and their shareholders. In this context, with the increase in internet access and intensive usage of social media platforms by individuals, social media platforms have become important mediums for organizations to introduce their corporate social responsibility projects to society and their stakeholders. In this study, the presentation shapes of corporate social responsibility actions have been focused within the context of developing communication technologies. Sabancı Holding and Koç Holding, which are two of the most important corporation groups of our country, carry out their corporate social responsibility actions through Sabancı Foundation and Vehbi Koç Foundation. In this regard, web site contents and Facebook social media shares between 1 March 2021 and 1 June 2021 of Sabancı Foundation and Vehbi Koç Foundation have been probed in qualitative and quantitative content analyses method.
\end{abstract}

Keywords: Corporate Reputation, Corporate Social Responsibility, Internet, Social Media, Facebook, Sabancı Foundation, Vehbi Koç Foundation.

Received: 28.05 .2021

Accepted: 01.09.2021

\section{Suggested Citation:}

Işık, G. and Toprak, Y. E. (2021). Presentation of Corporate Social Responsibility Actions in Digital Environment: Sabancı Foundation and Vehbi Koç Foundation, Journal of Social, Humanities and Administrative Sciences, 4(9): 903-923.

(C) 2021 Sosyal, Beşerî ve İdari Bilimler Dergisi. 


\section{Gíriş}

Kurumsal izleyiciler, yatırım yapma ve ürün seçme kararlarını verirken firmaların itibarlarını göz önünde bulundurmaktadırlar. İtibarlar; firmaların ürünlerinin, işlerinin, stratejilerinin nasıl olduğunu bildirmekle birlikte, rekabet içinde bulunan firmaların başarı kıyaslamalarını kamuoyuna sunmaktadır. Bu bağlamda, iyi itibara sahip olmak firmalara yönelik ekonomik anlamda olumlu geri bildirimler meydana getirmektedir (Akt. Fombrun ve Shanley, 1990:233).

Faaliyet gösterdiği alanda kaliteli ve kullanışlı ürün ve hizmetler sunmak, şirketlerin iyi bir kurumsal itibara sahip olabilmesi için yeterli değildir. Rekabetin hâkim olduğu günümüz tüketim toplumunda, şirketler hedef kitleleri tarafından sevilmeli, sayılmalı ve takdir edilmelidirler. Finansal açıdan güçlü olduklarını kanıtlayabilmeli ve hedef kitlelerine güven aşılayabilmelidirler. Misyon ve vizyonlarını açı ve net bir şekilde ortaya koyarak faaliyet sundukları alanda hem topluma hem de çalışanlarına liderlik edebilmelidirler. İyi yönetildiklerini ve nitelikli personellere sahip olduklarını topluma kabul ettirebilmelidirler. Yukarıda sayılan unsurları toplumun hassasiyetlerine duyarlı sosyal sorumluluk faaliyetleri ile sentezleyebilen şirketler, organik bir parçası olduğu toplum nezdinde iyi bir itibara sahip olmakta ve kendi faaliyet alanlarında rakiplerinin bir adım önüne geçmektedirler.

Sosyal ve çevresel sürdürülebilir kalkınmaya yönelik taleplerin arttı̆̆ı günümüz dünyasında, bir itibar bileşeni olarak kurumsal sosyal sorumluluğun önemi de giderek artmaktadır. Doğal yaşamı korumayı amaçlayan yeşil tüketimin ve sosyal bağlamda sorumlu yatırımların gelişimiyle, şirketlerin değerlendirme ve planlamalarında finansal etmenler kadar toplumsal faktörler de göz önünde bulundurulmaktadır. Uzman şirketler kurumsal faaliyetlerini çevresel ve toplumsal perspektiflerden gözlemlemekte ve değerlendirmekte; bu değerlendirmeleri temel alarak karar alan tüketici ve yatırımcılarına bilgi sağlamaktadırlar (Tanimoto, 2004:151).

İletişim ve özellikle internet teknolojilerin gelişimi, şirketlere paydaş olarak yer aldıkları sosyal sorumluluk faaliyetlerinin kamuoyuna sunumu bağlamında büyük avantajlar sağlamaktadır. Şirketler, sosyal sorumluluk faaliyetleri hakkında kamuoyu ile sürekli ve kesintisiz bir etkileşim halinde bulunabilmede, sosyal medya platformlarının önemini her geçen gün daha fazla kavramaktadır. Şöyle ki; söz konusu platformlarda kullanılan içerikler artık iletişim uzmanları tarafından şirketlerin finansal hedefleri ile toplumun şirketlerden beklentilerini ortak bir paydada buluşturabilecek iletişim stratejileri ile belirlenmektedir.

Bu bağlamda çalışmada Koç Holding'in Vehbi Koç Vakfı; Sabancı Holding'in Sabancı Vakfı aracılığı ile kurumsal itibarlarını sürdürebilmek ve arttırabilmek için uyguladığı kurumsal sosyal sorumluluk projeleri ele alınmaktadır. Söz konusu vakıfların web sitelerinde ve Facebook sosyal medya hesaplarında sosyal sorumluluk projelerini nasıl ve ne siklıkta kamuoyuna sunduğu, nitel ve nicel içerik analizi yöntemiyle analiz edilecektir.

\section{KURUMSAL ITİBAR KAVRAMI}

Fombrun (2001:293) kurumsal itibarı, "kilit durumdaki kaynak sağlayıcıların şirketin girişimciliğini yorumlamasını ve değerli çıtıtlar alma yeteneğini değerlendirmesini ifade eden, şirketin geçmişteki faaliyetleri ile gelecekteki beklentilerinin kolektif bir tasviri" olarak tanımlamıştır. Acquaah'a (2003:388) göre, bu tanımlama kurumsal itibarın firma ile paydaşları arasında sosyal olarak karmaşık olan bir etkileşim sonucunda geliştiği gerçeğine dayandırılmıştır. Bu bağlamda, kurumsal itibar firmanın geçmişi, şu anki faaliyetleri ya da gelecekteki bir olay karşısında nasıl 
davranacağı konusundaki eğilimlerine yönelik paydaşların izlenimlerini ifade etmektedir. Fombrun'ün "kimlikten itibara" modeli Şekil 1'de gösterilmiştir.

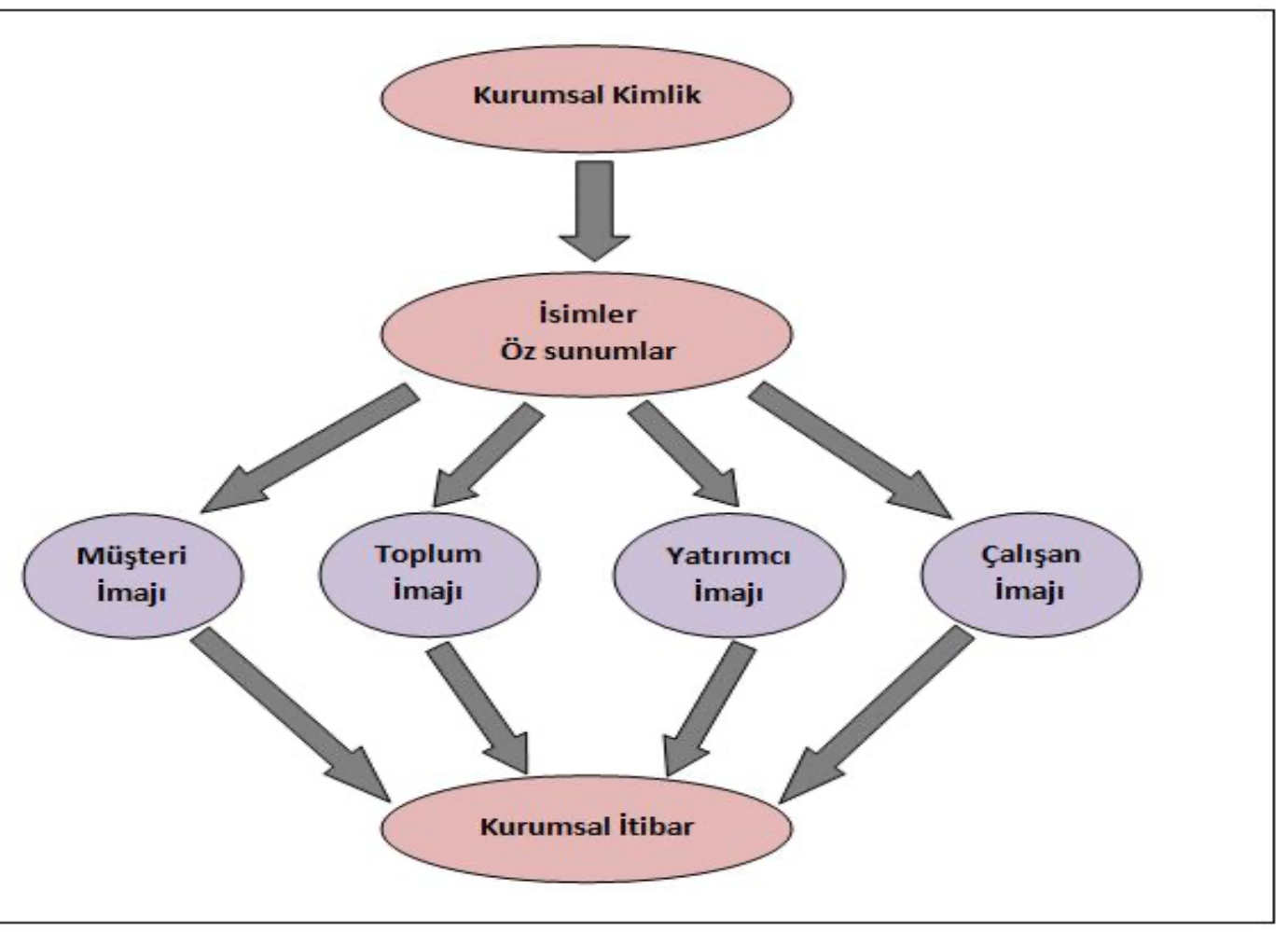

Şekil 1. Fombrun'ün Kurumsal İtibar Modeli

Kaynak: Lloyd, 2007:33.

Şekil 1'de de görüleceği üzere, Fombrun (1996:37) "kimlikten itibara" modelinde kimliğin; isimler ve öz sunumlar yoluyla sunulabileceğini ve müşteri, toplum, yatırımcı ve çalışan imajlarının bir yansıması olarak kurumsal itibara uzanabileceğini belirtmektedir. Fombrun için "Biz kimiz ve neyi temsil ediyoruz?" sorularının cevabı olarak kimlik; kültür, tarih ve yönetimi de kapsayan etkinlik bağlamında bir ayırt etme aracı olarak hizmet etmektedir.

"Kişilerin bir işletmeyle kurduklar etkileşim esnasinda kişisel ve çeoresel faktörlere bağh olarak elde ettikleri bilgiler bağlamında zihinlerinde oluşturduklar izlenim, düşünce ve görünüm" kurumsal imaj olarak tanımlanabilmektedir (Polat, 2009:2). Kurumsal itibar ise, toplumun işletmelerin performansları ve nitelikleri hakkında genel bir tahmine vurgu yapmaktadır. Kurumsal itibar kurumsal imajdan farklı olarak- etkili iletişim mekanizmalarıyla güçlendirilmiş tutarlı ve uzun vadeli performansla kazanılabilmektedir. Bu nedenle, inşa edilebilmesi belirli bir zaman gerektiren kurumsal itibarın; kurumsal imaja göre daha istikrarlı ve kalıcı bir yapıya sahip olduğu değerlendirilebilir (Bakan vd., 2019:200).

Fomburn (1996:36), günümüz şirketlerinin imaj ve itibar arasındaki farkı anlamaya başladığını kabul etmekle birlikte; kurumsal imajı bazı durumlarda şirketin kimliğini tam olarak yansıtan bir olgu olarak görmektedir. Bu bağlamda, kurumsal itibar imaj, ilişkiler ve kurumsal performansın bir sonucu olarak belirmeye başlamaktadır. Buna rağmen imaj iki biçimde çarpıtılmaktadır. Bunlardan ilki; şirketlerin reklam ve öz sunumların diğer biçimleriyle kamularını manipüle etmeleridir. İkincisi ise; şirket çalışanlarının çevrelerine ve analistlere yaptıkları gayri resmi açılamalar sonucunda ortaya çıkan dedikodulardır. Zaman içerisinde kimisi tutarlı, kimisi daha az tutarlı farklı imajlar oluşmaktadır. Gelinen noktada, imaj ve 
kurumsal kimlik arasında sürekli ve tutarlı bir uyuşma olması durumunda, kalıcı bir değer ortaya çıkmaktadır (Akt. Lloyd, 2007:32).

Fombrun, 4 Aralık 2000 tarihinde Financial Times gazetesinde The Value to Be Found in Corporate Reputation (Kurumsal İtibarda Bulunması Gereken Değer) başlığı ile yayımlanan yazısında, insanların şirketler hakkındaki algılarını özetlemek için bir indeks önermiş ve bu indekste katılımcıların şirketleri sevip sevmediklerine yönelik yorumlarından hareketle altı kategoriden oluşan faktörler belirlemiştir. Fombrun söz konusu altı faktörü kullanarak farklı paydaş gruplarının, şirketlerin itibarlarını nasıl gördüklerini değerlendirmek için "itibar katsayısı" geliştirmiştir. Bu katsayı Fombrun'e göre, kurumsal itibarı ölçmek için geçerli bir araçtır (Akt. Kitchen ve Watson, 2010). Fombrun'ün itibar ölçüm faktörleri Tablo1'de sunulmuştur.

Tablo 1. Fombrun'ün İtibar Ölçüm Faktörleri

\begin{tabular}{|l|l|}
\hline Duygusal çekicilik & $\begin{array}{l}\text { *Şirketin sevilme derecesi } \\
\text { *Şirkete saygı duyulma derecesi } \\
\text { *Şirketin takdir edilme derecesi }\end{array}$ \\
\hline Ürün ve hizmetler & $\begin{array}{l}* \text { İnsanların şirketin kalite, yenilik ve değerine yönelik algıları } \\
\text { *Şirketin ürün ve hizmetlerine duyulan güven }\end{array}$ \\
\hline Finansal performans & $\begin{array}{l}\text { *Insanların şirketin karlılığı, kazanç olasılığı ve riskleri üzerine } \\
\text { algıları }\end{array}$ \\
\hline Vizyon ve Liderlik & $\begin{array}{l}* \text { *Sirket vizyonunun açık ve netliği } \\
* \text { Güçlü liderlik }\end{array}$ \\
\hline İşyeri Çevresi & $\begin{array}{l}* \text { İnsanların şirketin iyi yönetilip yönetilmediğine, çalışanların şirket } \\
\text { hakkında tutumuna ve çalışanların kalitesine yönelik algıları }\end{array}$ \\
\hline Sosyal sorumluluk & $\begin{array}{l}* \text { İnsanların iyi bir yurttaş olarak topluma, çalışanlara ve çevreye } \\
\text { olan ilgisi bağlamında şirkete yönelik algıları }\end{array}$ \\
\hline
\end{tabular}

Kaynak: Kitchen ve Watson, 2010.

Tablo 1'de görüldüğü üzere Fombrun, itibar ölçümü için altı faktör ortaya koymuştur. Bunlardan ilki; şirketin sevilme, saygı duyulma ve takdir edilme derecesini kapsayan duygusal çekiciliktir. İkincisi; insanların şirketin kalite, yenilik ve değerlerine yönelik algıları ve şirketin ürün ve hizmetlerine duydukları güveni kapsayan ürün ve hizmetlerdir. Üçüncüsü; insanların şirketin karlılığı, kazanç olasılığı ve riskleri üzerine algılarını kapsayan finansal performanstır. Dördüncüsü; şirket vizyonunun açık ve netliği ile güçlü liderliği kapsayan vizyon ve liderliktir. Beşincisi; insanların şirketin iyi yönetilip yönetilmediğine, çalışanların şirket hakkında tutumuna ve çalışanların kalitesine yönelik algılarını kapsayan işyeri çevresidir. Altıncısı; insanların iyi bir yurttaş olarak topluma, çalışanlara ve çevreye olan ilgisi bağlamında şirkete yönelik algılarını kapsayan sosyal sorumluluktur.

Duygusal çekiciliğin ve kullanılan doğru iletişim tekniklerinin, kurumların olumlu bir itibar oluşturmasına katkısı oldukça önemlidir (Budak ve Budak, 2014:186). Nitekim kuruluşların kendisi ile hedef kitleleri arasındaki bağlantıyı iyi yönetmesi durumunda, pazar ile bağlantı 
kurabilmeleri de bir o kadar kolay olmaktadır. Bu noktada kurumu başarıya götürecek etmen, dış müşterisi olan tüketiciler ile iç müşterisi olan çalışanların mevcut işle ilgili ortak bir duygusal güvenceyi paylaşmasıdır. Öte yandan kurum çalışanlarının da iç hedef kitle kapsamında bilgilendirilmesi ve kurumun hedefleri doğrultusunda ikna edilmesi, dış hedef kitlenin iknasında oldukça önemlidir. Öyle ki bir iletişim kampanyasında, çalışanlar kurumun verdiği mesajı yaymak ve güçlendirmek için en önde görev alırlar. Çalışanların şirketin iletişim kampanya ve yöntemlerini benimsemedikleri durumlarda, hedef kitlenin ikna edilmesi zorlaşacaktır.

Fombrun'e (1996:67) göre, iletişim teknolojilerindeki gelişim ile birlikte, çalışanların şirketlere olan bağlılığı da artmaktadır. Bununla birlikte, işletmeler itibarlarını çalışanlarıyla karşılıklı güven oluşturarak sürdürebilmektedirler. Bu bağlamda, işletmeler tarafından çalışanların gelişimleri konusundaki taahhütlere uyulması, azınlıklar ve engelliler gibi gruplara karşı içten çabalar sergilenmesi sonucu oluşturulan çalışma ortamı, kurumsal itibarın yaratılması ve sürdürülebilmesi için son derece önemlidir (Akt. Yirmibeş, 2010:31).

İyi bir kurumsal itibar, müşterileri firmanın ürün ve hizmetlerine çekme, yetenekli ve becerikli çalışanları daha kolay bir şekilde işe alma ve finans kaynaklarına diğer rakip firmalara göre daha düşük bir maliyetle erişme gibi birçok avantajı da beraberinde getirmektedir. Buna ek olarak, iyi bir kurumsal itibar medyanın şirket hakkındaki algısını ve şirkete yönelik davranışlarını olumlu bir biçimde değiştirebilmekte, firmanın ürün ve hizmetleri için daha yüksek fiyatlar belirleyebilmesine olanak tanımakta ve firmaya pazarına girmeye çalışan rakip firmalara karşı kendisini savunabilme şansı vermektedir. Özetle, iyi bir kurumsal itibar, paydaşlar için firmanın çekiciliği ve verimliliğini ifade etmekte ve firmaya gelecekte bu paydaşlardan kâr elde etme fırsatı sunmaktadır (Acquaah, 2003:388-389).

Bu noktada finansal performans, "bir organizasyonun kârlllık ve yatırım amact ile rekabet edebilme ve risk edebilme yeteneği" olarak tanımlanmaktadır (Karatepe, 2008: 89). Buna göre teknik ve fiziksel donanım yetersizliği, örgütlerin hedeflerine ulaşmalarını engelleyen nedenlerinden birisidir. Küresel piyasada rakiplerine oranla daha fazla itibara sahip olan ve daha başarılı olan örgütler, ekonomik yapılarını güçlendiren örgütlerdir. Bu bağlamda, finansal performansı iyi olan bir örgüt; yüksek kâr elde etme olanağına sahiptir, riski düşük yatırımlar yapar, büyüme ile ilgili güçlü tahminlerde bulunur ve rakiplerinden daha iyi performans gösterir (Karaköse, 2007:47).

Kurumların itibarlarında önemli etkenlerden biri de liderliktir. Öyle ki, örgütlerin amaçlarının belirlenmesi ve bu amaçlara göre strateji ve vizyonlar geliştirilmesi liderin önderliğinde gerçekleşir. Bu bağlamda lider, vereceği kararlarla şirketin itibarından da sorumludur. Liderin önderliğinde belirlenen vizyonlar gerek iç çevre gerekse diş çevre tarafından olumsuz algılanmamalı, toplumsal hassasiyetler ile örgüt ve çalışanların değerleriyle örtüşmeli ve kurumsal itibarın gelişimine katkıda bulunmalıdır.

\section{BİR İTIBAR BİLEŞENI OLARAK KURUMSAL SOSYAL SORUMLULUK}

Uzun ve değişken bir tarihçeye sahip olan sosyal sorumluluk kavramı üzerine resmi anlamda üretilen yazımlar genellikle yirminci yüzyılın son elli yıllık bölümünün ürünüdür. Kurumsal sosyal sorumluluk kavramının izlerini dünya genelinde gelişmiş ülkelerde görmek mümkün olsa da; kurumsal sosyal sorumluluk ile ilgili yazımlar genellikle literatürün büyük bir bölümünün yer aldığı Amerika Birleşik Devletleri'nde görülmektedir (Carroll, 1999:238). 
Buna göre kurumsal sosyal sorumluluk, kimilerine göre hukuksal sorumluluk ve yükümlülüğü ifade ederken; kimilerine göre ise, etik anlamda sosyal olarak sorumlu davranışlar anlamını taşımaktadır (Votaw, 1972:25). Örneğin McGuire'e (1963:144) göre, sosyal sorumluluk işletmenin ekonomik ve hukuki yükümlülüklerinin yanı sıra, topluma karşı olan sorumluluklarının da bulunduğu fikrine dayanmaktadır. İşletme; toplumun refahı, çalışanlarının ve toplumsal çevrenin motivasyonu, eğitim ve politika konuları ile ilgilenmelidir. Benzer bir şekilde, sosyal sorumluluk ekonomik performansa ek olarak şirket tarafından ağırlık verilmesi gereken amaç ve hedeflerdir. Azınlık gruplarının işe alınması, kirliliğin azaltılması, toplumu geliştirmek için uygulanan programlarda daha fazla yer alma, iyileştirilmiş tıbbi destek, iyileştirilmiş endüstriyel sağlık ve güvenlik gibi yaşam kalitesini artırma amacı ile düzenlenmiş programlar sosyal sorumluluk şemsiyesi altında toplanmış faaliyetlerdir (Backman, 1975:2-3).

Burke ve Lonsdon'a (1996:496) göre, değer yaratımı genel olarak şirketin ve stratejik karar verme sürecinin en önemli unsuru olarak görülmektedir. Burke ve Longsdon'un amaç, görev ve hedef ile merkeziliği, rekabet avantajı ile belirliliği, plan ile proaktiviteyi, süreç ile gönüllülügü̈, yapı ile görünürlüğü bağdaştırdığı "değer yaratımında sosyal sorumluluk stratejilerinin boyutları" adlı modeli, Şekil 2'de gösterilmiştir.
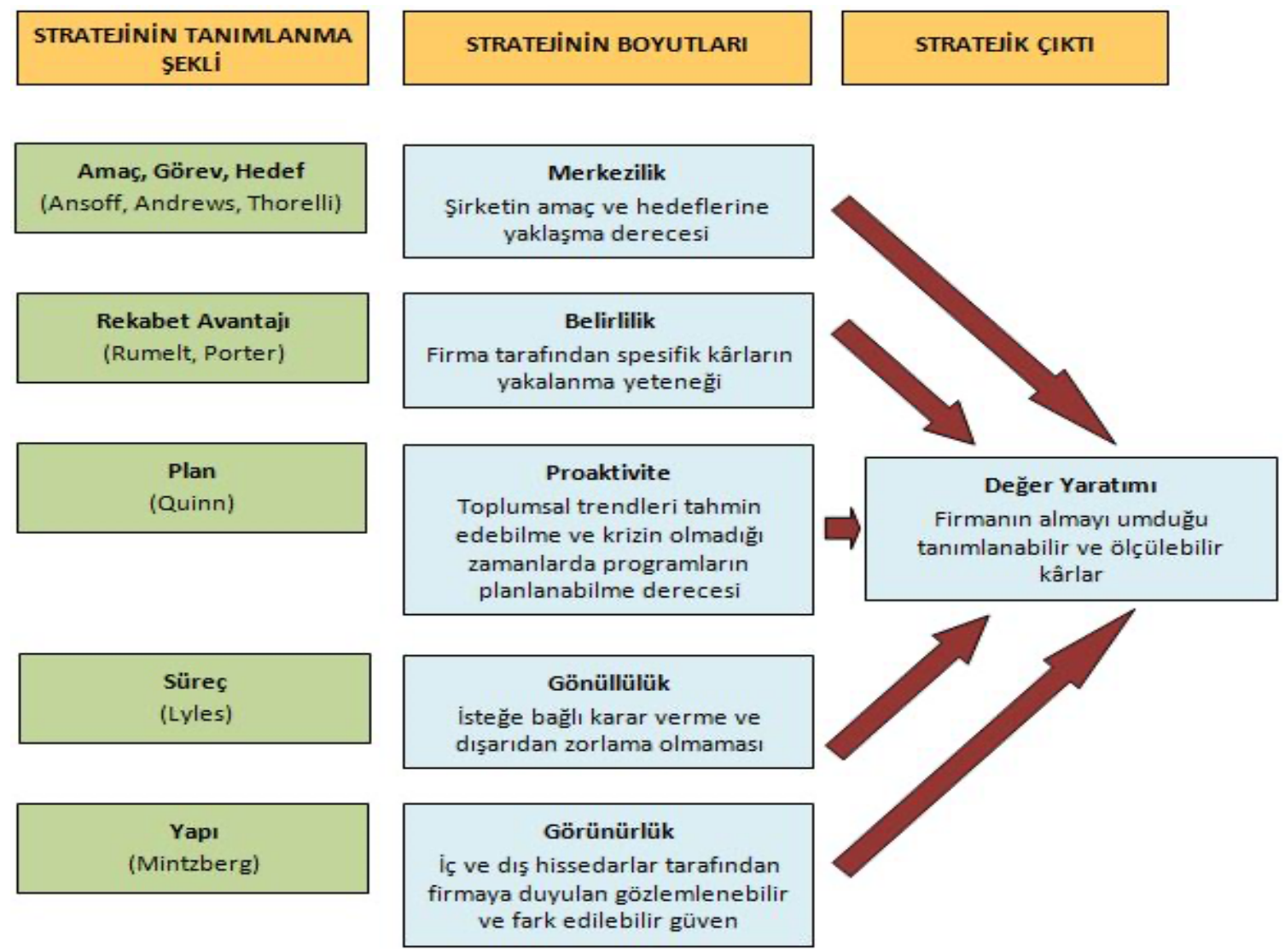

iç ve dış hissedarlar tarafından ve fark edilebilir güven

Şekil 2. Değer Yaratımında Sosyal Sorumluluk Stratejilerinin Boyutları Kaynak: Burke ve Longsdon, 1996: 497.

Buna göre sosyal sorumluluğun değer yaratımı üzerine muhtemel katkıları değerlendirildiğinde; Burke ve Longston tarafından şirketin amaç ve hedeflerine yaklaşma derecesi olarak tanımlanan "merkezilik", firma tarafından spesifik kârların yakalanma yeteneği olarak tanımlanan "belirlilik", toplumsal trendleri tahmin edebilme ve krizin olmadığı 
zamanlarda programların planlanabilme derecesi olarak tanımlanan "proaktiflik", isteğe bağlı karar verme ve dışarıdan zorlama olmadan karar verme olarak tanımlanan "gönüllülük", iç ve dış hissedarlar tarafından firmaya duyulan gözlemlenebilir ve fark edilebilir güven olarak tanımlanan "görünürlük" sosyal sorumluluğun stratejik önemde beş boyutu olarak ortaya çıkmaktadır.

Kurumsal sosyal sorumluluk kavramı, şirket ve toplum arasındaki ilişki göz önünde bulundurularak anlaşılabilir (Tanimoto, 2004:158). Davis ve Blomstrom (1966:12), sosyal sorumluluğu "bireyin karar ve faaliyetlerinin toplumsal sisteme olan etkilerini göz önünde bulundurma yükümlülüğü" olarak tanımlamışlardır. İş insanları iş ile ilgili faaliyetlerinden etkilenen insanların ihtiyaç ve alakalarını göz önünde bulundurduklarında sosyal sorumluluğa başvururlar ve bu şekilde davranarak, şirketlerinin ekonomik ve teknik amaçlarının çok daha ötesine bakmış olurlar. Bugünün küresel dünyasında kurumsal sosyal sorumluluk yeni ve gelişen bir finansal risk faktörü durumuna da gelmiştir. Yanlış yönetildiği takdirde, firmaların kurumsal itibarı zarar görebilir. Bununla birlikte, firmalar iş hacimlerinde ve kârlarında olumsuz bir etki ile yüzleşmek durumunda kalabilirler (Ogrizek, 2002:215).

Kurumsal sosyal sorumluluk, Ekonomik Kalkınma ve İşbirliği Örgütü (Organisation for Economic Cooperation and Development-OECD) üyesi hükümetlerin politik ajandalarında önemli bir yere sahiptir. Birçok grup, sektör ve paydaş için farklı anlamlar taşısa da sosyal sorumluluğun "şirketlerin sürdürülebilir gelişimine katkısı" tanımı genel anlamda kabul görmüştür. Şirketler artık sadece vergilerini ödeyerek ve yasalara uyarak varlıklarını sürdüremeyeceğini anlamış ve bunlarla birlikte toplumdaki etkilerini yönetmek için daha fazla sorumluluk almaları gerektiğinin farkına varmıştır (Nourick, 2001:13-14).

Grunig ve Hunt, kamusal ya da sosyal sorumluluğun organizasyonun halkla ilişkiler fonksiyonuna sahip olması için çok önemli bir sebep olduğunu ve iki yönlü simetrik iletişimin sosyal sorumluluğun değerlendirilmesinde en iyi araç olduğunu ifade etmişlerdir. İki yönlü simetrik model ile iyi planlanmış iki yönlü bilgi akışı neticesinde hem organizasyon hem de paydaşlar davranışlarını ve tutumlarını değiştirebilmektedirler (Akt. Clark, 2000:368).

Garriga ve Mele (2004: 52-53) ise kurumsal sosyal sorumlulukla ilgili teorileri işletme ve toplum arasındaki etkileşim bağlamında dört ana başlık altında kategorize etmişlerdir. Söz konusu kategorizasyona göre oluşturulmuş görsel Şekil 3'te sunulmuştur.

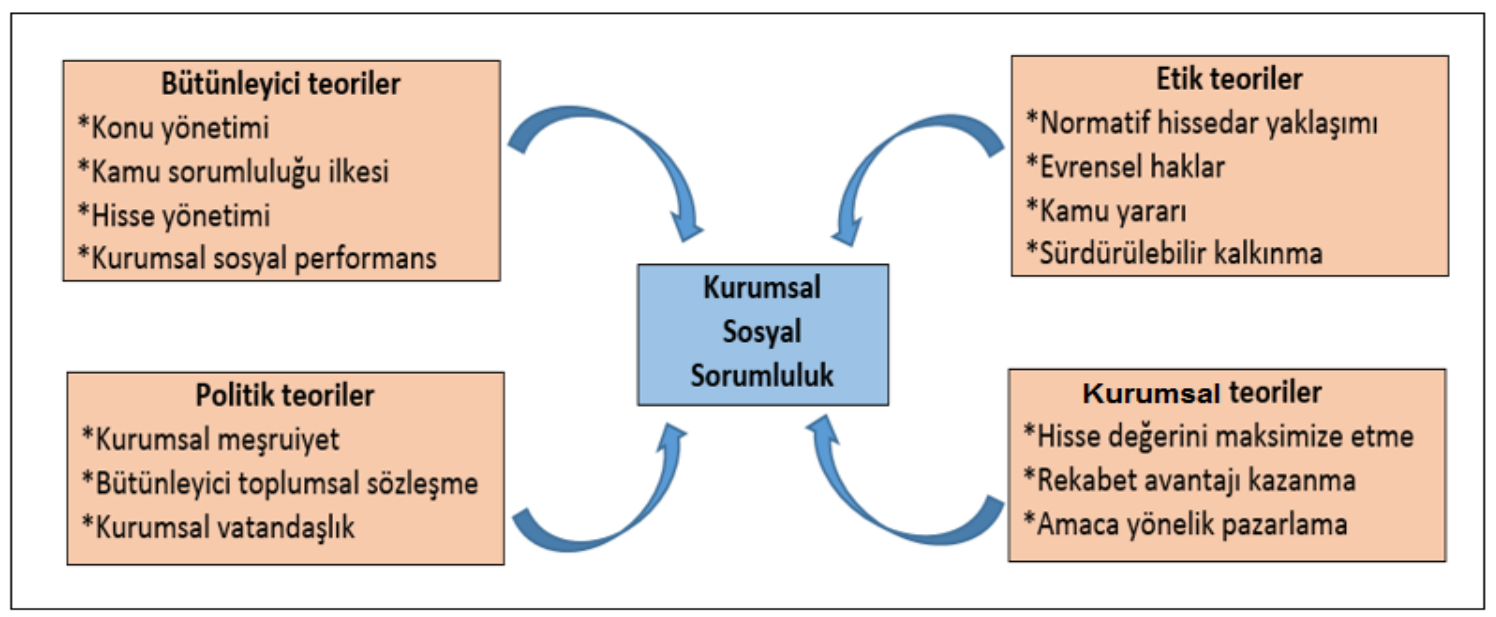

Şekil 3. Kurumsal Sosyal Sorumluluğa Kuramsal Yaklaşımlar

Kaynak: Garriga ve Mele, 2004: 52-53. 
Şekil 3'te görüleceği üzere, kurumsal sosyal sorumluluğa yönelik dört kuramsal yaklaşım bulunmaktadır. Kurumsal sosyal sorumluluğun ekonomik amaçları başarmak için stratejik bir araç olarak görülerek, sadece karı arttırmak olarak değerlendirildiği "kurumsal teoriler" ilk yaklaşımı oluşturmaktadır. Kurumun toplum ve politik alandaki sorumlulukları ile ilişkisinin, yani sosyal gücünün vurgulandığı "politik teoriler" ikinci yaklaşımı oluşturmaktadır. Şirketlerin varlıklarını ve büyümelerini sürdürebilmelerinin, içinde bulundukları topluma bağlı olduğunu ve bunun sonucu olarak, işletmelerin toplumun sosyal taleplerini yeterine getirmeleri gerektiği düşüncesinden ortaya çıkan "bütünleyici teoriler" üçüncü yaklaşımı oluşturmaktadır. İşletmeler ile toplum arasındaki ilişkilerin etik değerler doğrultusunda yapılması gerekliliğinin ve işletmelerin sosyal sorumlulukların göz önünde bulundurdukları hususların en üstünde etik bir yükümlülük olarak görmelerinin vurgulandığı "etik teoriler" ise dördüncü yaklaşımı oluşturmaktadır.

İşletme politikalarını kurumsal sosyal sorumluluk stratejileri ile birleştiren şirketler, belirgin ve elle tutulur karlar elde etmenin yanı sıra rekabet avantajı da kazanmaktadırlar (Ogrizek, 2002:220). Bununla birlikte, araştırmalar kurumsal sosyal sorumluluğun çalışanlar ve müşteriler üzerindeki etkileri üzerine de odaklanmaya başlamıştır (Akt. Chahal ve Sharma, 2006:208). Tüketiciler, firmaların kurumsal sosyal sorumluluklarına daha fazla ilgi duymaya ve tüketim kararlarını firmaların kurumsal sosyal performansları bağlamında vermeye başlamışlardır (Tanimoto, 2004:151). Zira Creyer (1997:421), etik ve müşteri tercihleri arasında da olumlu bir ilişki olduğunu ileri sürmüş; Handelman ve Arnold (1999:33) da kurumsal sosyal sorumluluk ile iş performansı arasındaki olumlu ilişki nedeniyle şirketlerin etik stratejileri ile ekonomik odaklı pazarlama stratejilerini bütünleştirdiklerini belirtmişlerdir.

Carroll (1991:40), ortaya koyduğu kurumsal sosyal sorumluluk piramidi ile "ekonomik", "yasal", "etik" ve "gönüllülük"ten oluşan dört sosyal sorumluluk alanının bütüncül sosyal sorumluluğu oluşturduğunu ifade etmektedir. Carroll, ekonomik ve yasal sorumlulukların belirli ölçülerde işletmelerle birlikte her zaman var olduğunu; fakat etik ve gönüllü sorumluluğun daha sonradan önem kazandığını vurgulamaktadır. Carroll'un kurumsal sosyal sorumluluk piramidi Şekil 4'te sunulmuştur.

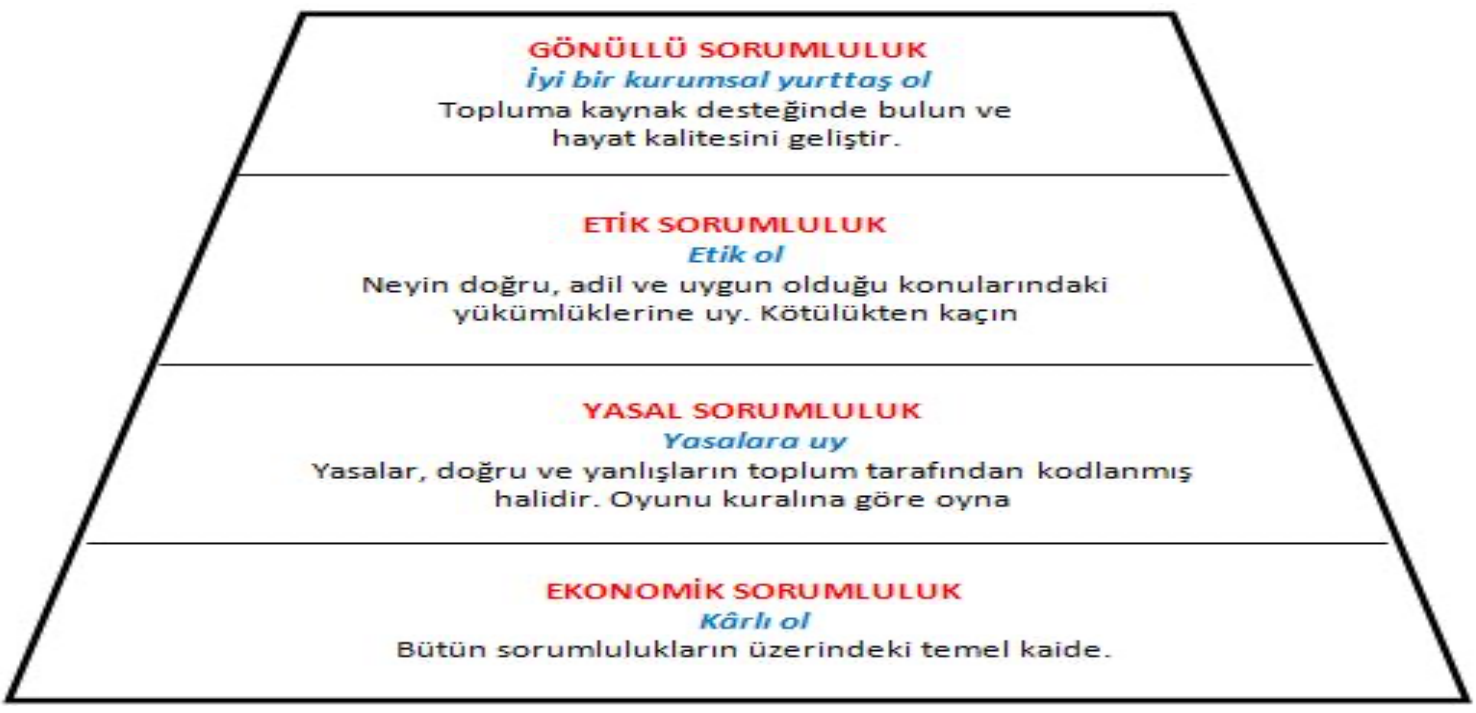

Şekil 4. Carroll'un Kurumsal Sosyal Sorumluluk Piramidi

Kaynak: Carroll, 1991: 42. 
Şekil 4'ten de anlaşılacağı üzere bütün işletme sorumlulukları şirketin ekonomik sorumluluklarına dayanmaktadır. Çünkü ekonomik sorumlulukların olmadığı bir ortamda diğer sorumlulukların önemi azalır. Bu bağlamda, sosyal sorumluluk piramidinin temelini ekonomik sorumluluklar oluşturur. Toplumsal sözleşmenin bir unsuru olarak, şirketler ekonomik görevlerini hukuk çerçevesinde yerine getirmelidirler. Ekonomik ve hukuki sorumluluklar dürüstlük ve adalet gibi etik normları içerse de etik sorumluluklar hukuki olarak tanzim edilmemiş olmasına rağmen toplumu oluşturan bireyler tarafından istenen ve istenmeyen faaliyet ve pratikleri kapsamaktadır. Gönüllü sorumluluklar ise toplumun işletmenin iyi bir kurumsal yurttaş olması yönündeki beklentisi üzerine işletme tarafından icra edilen kurumsal faaliyetleri içermektedir (Carroll, 1991:40-42).

Son ylllarda küreselleşme, geleneksel kapitalist düşünceyi hem piyasa hem de toplumu içine alacak şekilde yeniden yapılanma konusunda zorlamaktadır. Küreselleşme, kurumsal yurttaşlık ve kurumsal itibar konuları üzerinde çok önemli bir etkiye sahiptir. Faaliyet gösterdikleri alanların birleştirici unsuru olarak şirketler, "kurumsal yurttaşlar" olarak değerlendirilmektedirler (Ogrizek, 2002:216). İşletmeler faaliyet gösterdiği toplumu hesaba katmak zorunda oldukları için, iş dünyası ve yöneticiler arasında oldukça popüler bir kavram olan kurumsal yurttaşlık terimi; bir topluma ait olma düşüncesini çağrıştırmaktadır. Kurumsal yurttaşlık toplumdaki bir işletmenin haklarına, sorumluluklara ve muhtemel ortaklıklarına odaklanmaktadır. Terim üzerine farklı tanımlamalar yapılmış olsa da kurumsal yurttaşlığın literatürde genel anlamda kabul görmüş tanımı, işletmenin yerel toplumu geliştirmedeki istek ve arzusu ile çevre hakkındaki duyarlılığının üst seviyede olmasıdır (Garriga ve Mele, 2004:57).

Buraya kadar bahsedilenlerden de anlaşılacağı üzere kurumlar, görev çevresi ve sosyokültürel normlardan oluşan kompleks bir çevresel sistemin organik ve bölünmez bir parçasıdır (Dacin, 1997:46). Meyer ve Scott'a (1992:1) göre, organizasyon sınırl kaynaklar için rekabet eden mahdut bir aktör olmaktan ziyade, içinde bulunduğu çevre ile iç içe girmiştir. Bu nedenle, organizasyonun yapısı ve faaliyetleri içinde bulunduğu çevrenin normlarını yansıtmaktadır. Rasyonel stratejik amaçların sonucu olmanın ötesinde, organizasyonlar teknik akıcılık ve toplumsal süreçten toplumsal bütünleşme ve adalete kadar büyük toplumsal amaçların meşru araçlarıdır (Akt. Handelman ve Arnold, 1999: 34). Bu noktada, organizasyon ile refahına etki ettiği toplum arasında bir toplumsal sözleşme ortaya çıkmaktadır (Robin ve Reidenbach, 1987:45).

\section{YÖNTEM}

Araştırmanın amacı Sabancı Vakfı ve Vehbi Koç Vakfı'nın kurumsal itibarını sürdürebilmek ve arttırabilmek için uyguladığı sosyal sorumluluk projelerini, web sitelerinden ve resmi Facebook hesaplarından kamuoyuna nasıl, ne sıklıkta ve hangi içerikler ile sunduğunu analiz etmektir. Bu bağlamda, Sabancı Vakfı ve Vehbi Koç Vakfı projelerinin web sitesi ve Facebook sosyal ağ platformundan sunumuna odaklanan bu araştırma, betimleyici bir araştırmadır. Niteliksel ve niceliksel araştırma tasarımının kullanıldığı bu çalışmada Vehbi Koç Vakfı ve Sabancı Vakfı sosyal sorumluluk paylaşımları içerik analizi yöntemiyle incelenmiştir. İnceleme kapsamında yer alan dönemde vakıfların web sitesi ve Facebook sosyal ağ platformunda yayımladığ kurumsal sosyal sorumluluk içeriklerine odaklanılmasının nedeni, internetin ve sosyal medyanın en çok kullanılan iletişim araçlarından olması ve özellikle sosyal medyanın karşııklı iletişime olanak vererek kurum ve kullanıcı arasında bir etkileşim oluşturmasıdır. 


\section{Örneklem}

Araştırmanın evreni Vehbi Koç Vakfı ve Sabancı Vakfı'dır. Araştırmanın örneklemi ise söz konusu vakıfların web sitesi içerikleri ile resmi Facebook hesaplarında 1 Mart 2021-1 Haziran 2021 tarihleri arasında kalan üç aylık dönemde yayımlanan 106 Facebook içeriğinin tamamıdır. Söz konusu tarih aralığının seçilmesinin nedeni; Kadınlar Günü, Anneler Günü, Dünya Sağlık Günü, Dünya Sokak Hayvanları Günü, Dünya Otizm Farkındalık Günü, Dünya Tiyatro Günü, Uluslararası Hemşireler Günü, Emek ve Dayanışma Günü, Sosyal Girişimcilik Günü, Vakıflar Haftası, Engelliler Haftası, Müzeler Haftası, Ramazan Bayramı, Çanakkale Deniz Zaferi, Ulusal Egemenlik ve Çocuk Bayramı, Gençlik ve Spor Bayramı, Tıp Bayramı gibi özel günlerin bu tarihler arasında yoğunlaşmış olmasıdır. İçerik analizi uygulamasının ilk bölümünde vakıflara ait web siteleri, ikinci bölümde vakıfların Facebook hesapları incelenmiştir.

\section{Çözümleme Kategorisi}

Web sitesi analizinde kodlama cetveli daha önce Kanada'da bulunan kâr amacı gütmeyen çevreci grupların web varlıklarını inceleyen ve bu bağlamda 43 kuruluşun web sitelerini inceleyen Greenberg ve MacAulay (2009:63-69) tarafından oluşturulmuş 3 kategoriye göre hazırlanmıştır. Bu 3 kategorinin yer aldığı araştırmada Yılmazel'in (2011:64) daha önce hazırladığ 28 kriterden oluşan kodlama cetvelinden yararlanılarak 43 kriterden oluşan yeni bir kodlama cetveli oluşturulmuştur. Kodlama cetvelinde bulunan 3 kategori ve 43 kriter aşağıda belirtilmiştir:

Vakıfla ilgili genel bilgileri açıklama kategorisi: Bu kategoride "vakfın tanımı", vakfın tarihçesi", "vakfın misyon ve amaçları", "vakfın kurucu bilgileri", "vakfın posta adresi", "vakfın telefon/faks numarası", "vakfın elektronik posta adresi", "vakfın logosu", "vakfın harita görseli", "resmi senet", "finansal bilgiler", "vakfın üyesi olduğu kuruluşlar", "vakfın aldığı ödüller", "kurumsal yapı", "faaliyet haritası", "vakfın alt kuruluşları", "vakfa ait Facebook sayfasına bağlantı", "vakfa ait Twitter sayfasına bağlantı", "vakfa ait YouTube sayfasına bağlantı" ve "vakfa ait Instagram sayfasına bağlantı" olmak üzere toplam 20 kriter bulunmaktadır.

Vakıfla ilgili bilgilerin paylaşım kategorisi: Bu kategoride "projeler", "fotoğraflar", "videolar", "oturum açma bağlantısı", "elektronik bülten üyelik bağlantısı", "basın bültenleri", "basında yer alan bilgi/haberler", "duyurular", "kalıcı eserler", "eğitim/burs", "kültür/sanat", "sağlık", "spor" ve "vakfın verdiği ödüller" olmak üzere toplam 14 kriter bulunmaktadır.

Üyelerle bağ kurma kategorisi: Bu kategoride "etkinlikler", "gönüllülük seçenekleri", "bağışta bulunma", "iletişim formu", "arkadaşına öner/paylaş", "Facebook üyeliği", "Twitter üyeliği", "YouTube üyeliği" ve "Instagram üyliği" olmak üzere toplam 9 kriter bulunmaktadır

Facebook analizi 3 kategoriye göre hazırlanmıştır. Bu üç kategorinin yer aldığı analizde toplam 21 kriterden oluşan kodlama cetveli oluşturulmuştur. Bunlar:

İçeriklerin Sayısal Değerleri: Bu kategoride "toplam içerik sayısı", "içeriklerin toplam beğenilme sayısı", "içeriklerin toplam paylaşılma sayısı" ve "içeriklerin toplam yorumlanma sayısı" olmak üzere toplam 4 kriter bulunmaktadır. Her iki vakfın da Facebook hesaplarında paylaştıkları içerikler -silinmedikleri sürece- sürekli olarak beğenilmekte, paylaşılmakta ve yorumlanmaktadır. Analiz kapsamında kodlama cetveline konu nicel veriler 2 Haziran 2021 tarihinde kayıt edilmiştir. 
İçeriklerin Konuları: Bu kategoride "kültür ve sanat", "eğitim/burs", "toplumsal cinsiyet eşitliliği ve kadına yönelik", "aile içi şiddete karşı çıkmaya yönelik", "toplumsal değişim", "özel gün paylaşımları", "girişimcilik/motivasyon/tasarımcılık", "sağlık", "anma", "vakıf tarafından verilen ödüller", "vakıfa verilen ödüller", "engelli yurttaşlara yönelik", "kültür, eğitim ve sağlık alanında kalıcı eserler", "hayvan hakları ve doğayı korumaya yönelik" ve "faaliyet raporu" olmak üzere toplam 15 kriter bulunmaktadır.

İçeriklerin Türü: Bu kategoride "fotoğraf" ve "video" olmak üzere toplam 2 kriter bulunmaktadır.

\section{Çözümleme Birimleri}

Geray'a (2006:150) göre, çözümleme birimleri dilsel birimler (kelimeler, cümleler, paragraflar) ve dilsel olmayan birimler (belgenin tümü, belgenin parçaları, karakterler) olarak sınıflandırılmaktadır (Akt. Çelik ve Aydın, 2016:230). Bu bağlamda, bu araştırmadaki çözümleme birimi, dilsel olmayan birimlerden belgenin bütünüdür. Bu araştırmadaki temel sayma birimi, Vehbi Koç Vakfı ve Sabancı Vakfı web siteleri ve resmi Facebook hesaplarında yayımlanan içerikler olarak belirlenmiştir. Bu kapsamda, sosyal sorumluluk projelerinin içerik analizinde kullanılan temel kategorilere göre frekans dağılımları sunulmuştur. İncelemede kapsamında yer alan dönemde Vehbi Koç Vakfı ve Sabancı Vakfı projelerinin web siteleri ve resmi Facebook hesapları üzerinden sunumuna odaklanılan bu çalışmada radyo, televizyon, gazete, dergi, gibi diğer iletişim araçları dikkate alınmamıştır. Bu bağlamda, araştırma bulguları değerlendirilirken bu sınırlılık göz önünde bulundurulmalıdır.

\section{BULGULAR}

\section{Web Sitesi Bulguları}

\section{Vakıfla İlgili Genel Bilgileri Açıklama Kategorisi Bulguları}

Sabancı Vakfı ve Vehbi Koç Vakfı'nın kurumsal web sitelerinin kendileriyle ilgili bilgileri açıklama kategorisi bulguları Tablo 2'de sunulmuştur.

Tablo 2'de sunulduğu üzere, vakıflarla ilgili genel bilgileri açıklama kategorisi altında, vakıflara ait web siteleri 20 kriter açısından incelenmiştir. Bu bağlamda, Sabancı Vakfı'nın kriterleri karşılama oranı \%95 iken; Vehbi Koç Vakfı'nın kriterleri karşılama oranı \%90 olarak hesaplanmıştır. Her iki vakfın da kriterleri karşılama oranları tatmin edici düzeydedir. Günümüzde sosyal medya kullanımı giderek yaygınlaşmaktadır. Gerek Sabancı Vakfı'nın gerekse Vehbi Koç Vakfi'nın web siteleri üzerinden Facebook, Twitter, YouTube ve Instagram gibi yaygın sosyal ağ platformlarına bağlantı sağlamak suretiyle; üyeleriyle kurdukları iletişim ve etkileşimi etkili ve sürekli bir hale getirmeyi amaçladığı sonucuna ulaşılabilir. Bununla birlikte, resmi senet vakfın kamuoyu tarafından daha şeffaf bir şekilde algılanmasını kolaylaştırmaktadır. Bu bağlamda; yasal, toplumsal ve ekonomik sorumluluklarını resmi senet olarak web sitesinde paylaşan Sabancı Vakfı'nın; Vehbi Koç Vakfı'nın bir adım önünde olduğu değerlendirilebilir. 
Tablo 2. Vakıf Web Sitelerinin Kendileriyle İlgili Genel Bilgileri Açılama Kategorisi Bulguları

\begin{tabular}{|c|c|c|c|}
\hline S. Nu. & Kriter & Sabancı Vakfı & Vehbi Koç Vakfı \\
\hline 1 & Vakfın tanımı & $\checkmark$ & $\checkmark$ \\
\hline 2 & Vakfın tarihçesi & $\checkmark$ & $\checkmark$ \\
\hline 3 & Vakfın misyon ve amaçları & $\checkmark$ & $\checkmark$ \\
\hline 4 & Vakfın kurucu bilgileri & $\checkmark$ & $\checkmark$ \\
\hline 5 & Vakfın posta adresi & $\checkmark$ & $\checkmark$ \\
\hline 6 & Vakfın telefon/fax numarası & $\checkmark$ & $\checkmark$ \\
\hline 7 & Vakfın elektronik posta adresi & $\checkmark$ & $\checkmark$ \\
\hline 8 & Vakfın logosu & $\checkmark$ & $\checkmark$ \\
\hline 9 & Vakfın harita görseli & $\checkmark$ & $\checkmark$ \\
\hline 10 & Resmi senet & $\checkmark$ & $x$ \\
\hline 11 & Finansal bilgiler & $\checkmark$ & $\checkmark$ \\
\hline 12 & Vakfın üyesi olduğu kuruluşlar & $\checkmark$ & $x$ \\
\hline 13 & Vakfın aldığı ödüller & $\checkmark$ & $\checkmark$ \\
\hline 14 & Kurumsal yapı & $\checkmark$ & $\checkmark$ \\
\hline 15 & Faaliyet haritası & $\checkmark$ & $\checkmark$ \\
\hline 16 & Vakfın alt kuruluşları & $\mathrm{x}$ & $\checkmark$ \\
\hline 17 & Vakfa ait Facebook sayfasına bağlantı & $\checkmark$ & $\checkmark$ \\
\hline 18 & Vakfa ait Twitter sayfasına bağlantı & $\checkmark$ & $\checkmark$ \\
\hline 19 & Vakfa ait YouTube sayfasına bağlantı & $\checkmark$ & $\checkmark$ \\
\hline 20 & Vakfa ait Instagram sayfasına bağlantı & $\checkmark$ & $\checkmark$ \\
\hline & Toplam & $19(\% 95)$ & $18(\% 90)$ \\
\hline
\end{tabular}

\section{Vakıfla İlgili Bilgilerin Paylaşımı Kategorisi Bulguları}

Sabancı Vakfı ve Vehbi Koç Vakfı'nın kurumsal web sitelerinin kendileriyle ilgili bilgileri paylaşma kategorisi bulguları Tablo 3'te sunulmuştur.

Tablo 3. Vakıf Web Sitelerinin Kendileriyle İlgili Bilgileri Paylaşma Kategorisi Bulguları

\begin{tabular}{|c|l|c|c|}
\hline S. Nu. & Kriter & Sabancı Vakfi & Vehbi Koç Vakfı \\
\hline 1 & Projeler & $\checkmark$ & $\checkmark$ \\
\hline 2 & Fotoğraflar & $\checkmark$ & $\checkmark$ \\
\hline 3 & Videolar & $\mathbf{x}$ & $\checkmark$ \\
\hline 4 & Oturum açma bağlantısı & $\checkmark$ & x \\
\hline 5 & Elektronik bülten üyelik bağlantısı & $\checkmark$ & $\checkmark$ \\
\hline 6 & Basın bültenleri & $\checkmark$ & $\checkmark$ \\
\hline 7 & Basında yer alan bilgi/haberler & $\checkmark$ & $\checkmark$ \\
\hline 8 & Duyurular & $\checkmark$ & $\checkmark$ \\
\hline 9 & Kalıcı eserler & $\checkmark$ & $\checkmark$ \\
\hline 10 & Eğitim/burs & $\mathbf{x}$ & $\checkmark$ \\
\hline 11 & Kültür/sanat & $\checkmark$ & $\checkmark$ \\
\hline 12 & Sağlık & $\checkmark$ & x \\
\hline 13 & Spor & $12(\% 85,71)$ & $\checkmark$ \\
\hline 14 & Vakfın verdiği ödüller & & $11(\% 78,57)$ \\
\hline Toplam & & $\checkmark$ & $\checkmark$ \\
\hline
\end{tabular}


Tablo 3'te sunulduğu üzere, vakıfla ilgili bilgileri paylaşma kategorisi altında, vakıflara ait web siteleri 14 kriter açısından incelenmiştir. Bu bağlamda, Sabancı Vakfı'nın kriterleri karşılama oranı \%85,71 iken; Vehbi Koç Vakfı'nın kriterleri karşılama oranı \%78,57 olarak hesaplanmıştır. Her iki vakfın da kriterleri karşılama oranları tatmin edici düzeydedir. Hem Sabancı Vakfı'nda hem de Vehbi Koç Vakfi'nda oturum açma bağlantısının bulunmadığı görülmüştür. Bu durumun, vakıfların sosyal medya hesaplarını etkin bir şekilde kullanmasının bir sonucu olduğu düşünülebilir. Sabancı Vakfı web sitesinde sağlık ile ilgili, Vehbi Koç Vakfı web sitesinde ise spor ile ilgili herhangi bir içerik görülmemiştir. Sabancı Vakfı'nın içeriklerini basın bültenleri ile destekleyerek, kendisi ile ilgili bilgilerin paylaşımı konusunda avantaj sağladığı değerlendirilebilir.

\section{Üyelerle Bağ Kurma Kategorisi Bulguları}

Sabancı Vakfı ve Vehbi Koç Vakfi'nın kurumsal web sitelerinin üyelerle bağ kurma kategorisi bulguları Tablo 4'te sunulmuştur.

Tablo 4. Vakıfların Üyelerle Bağ Kurma Kategorisi Bulguları

\begin{tabular}{|c|l|c|c|}
\hline S. Nu. & Kriter & Sabancı Vakfı & Vehbi Koç Vakfı \\
\hline 1 & Etkinlikler & $\checkmark$ & $\checkmark$ \\
\hline 2 & Gönüllülük seçenekleri & $\checkmark$ & $\checkmark$ \\
\hline 3 & Bağışta bulunma & $\mathbf{x}$ & $\mathbf{x}$ \\
\hline 4 & İletişim formu & $\checkmark$ & $\mathbf{x}$ \\
\hline 5 & Arkadaşlarına öner/paylaş & $\mathbf{x}$ & $\mathbf{x}$ \\
\hline 6 & Facebook üyeliği & $\checkmark$ & $\checkmark$ \\
\hline 7 & Twitter üyeliği & $\checkmark$ & $\checkmark$ \\
\hline 8 & YouTube üyeliği & $\checkmark$ & $\checkmark$ \\
\hline 9 & Instagram üyelĭ̆i & $7(\% 77,77)$ & $6(\% 66,66)$ \\
\hline
\end{tabular}

Tablo 4'te sunulduğu üzere, vakıfların üyeleriyle bağ kurma kategorisi altında, vakfa ait web siteleri 7 kriter açısından incelenmiştir. Bu bağlamda, Sabancı Vakfı'nın kriterleri karşılama oranı \%77,77 iken; Vehbi Koç Vakfı'nın kriterleri karşılama oranı \%66,66 olarak hesaplanmıştır. İki vakıf arasında üyelerle bağ kurma kategorisi bağlamında önemli bir farklılık yoktur. Her iki vakfın web sitesinde de bağışta bulunmaya ve arkadaşlarına öner/paylaşa yönelik bir bağlantıya rastlanmamıştır. Sabancı Vakfı iletişim sekmesi altında iletişim formuna yer verirken, Vehbi Koç Vakfı iletişim sekmesi altında herhangi bir iletişim formu bulunmamaktadır.

\section{Facebook Bulguları}

\section{İçeriklerin Sayısal Değerlerine Yönelik Bulgular}

Vakıflar tarafından yayımlanan Facebook içeriklerinin toplam sayısal değerleri Tablo 5 'te sunulmuş̧tur. Tablo 5 'te sunulduğu üzere, Sabancı Vakfı üç aylık zaman diliminde Facebook'ta 66 içerik yayımlamıştır. Bu içerikler 15 bin 148 kez beğenilmiş, 2 bin 191 kez paylaşılmış ve 397 
kez yorumlanmışır. Vehbi Koç Vakfı ise aynı zaman diliminde 40 içerik yayımlamıştır. Bu içerikler 2 bin 357 kez beğenilmiş 434 kez paylaşılmış ve 63 kez yorumlanmıştır.

Tablo 5. Vakıflar Tarafından Yayımlanan Facebook İçeriklerinin Toplam Sayısal Değerleri

\begin{tabular}{|c|c|c|c|c|}
\hline Vakıf Adı & $\begin{array}{c}\text { Toplam İçerik } \\
\text { Sayısı }\end{array}$ & Toplam Beğeni & $\begin{array}{c}\text { Toplam } \\
\text { Paylaşım }\end{array}$ & $\begin{array}{c}\text { Toplam } \\
\text { Yorum }\end{array}$ \\
\hline Sabancı Vakfı & 66 & 15148 & 2191 & 397 \\
\hline Vehbi Koç Vakfı & 40 & 2357 & 434 & 63 \\
\hline
\end{tabular}

Vakıflar tarafından yayımlanan Facebook içeriklerinin ortalama sayısal değerleri Tablo 6'da sunulmuştur.

Tablo 6. Vakıflar tarafından yayımlanan Facebook içeriklerinin ortalama sayısal değerleri

\begin{tabular}{|c|c|c|c|c|}
\hline Vakıf Adı & $\begin{array}{c}\text { Günlük } \\
\text { Ortalama İçerik } \\
\text { Sayısı }\end{array}$ & $\begin{array}{c}\text { İçerik Başına } \\
\text { Ortalama } \\
\text { Beğeni }\end{array}$ & $\begin{array}{c}\text { İçerik Başına } \\
\text { Ortalama } \\
\text { Paylaşım }\end{array}$ & $\begin{array}{c}\text { İçerik Başına } \\
\text { Ortalama } \\
\text { Yorum }\end{array}$ \\
\hline Sabancı Vakfı & 0,71 & 229,51 & 33,19 & 6,01 \\
\hline Vehbi Koç Vakfı & 0,43 & 58,92 & 10,85 & 1,58 \\
\hline
\end{tabular}

Tablo 6'da sunulan bilgiler 1şı̆̆ında, Sabancı Vakfı günde ortalama 0,71 içerik yayımlarken; Vehbi Koç Vakfı günde ortalama 0,43 içerik yayımlanmaktadır. İçerik başına ortalama beğeni sayısı Sabancı Vakfı'nda 229,51 iken; Vehbi Koç Vakfı'nda 58,92'dir. İçerik başına ortalama paylaşım sayısı Sabancı Vakfı'nda 33,19 iken; Vehbi Koç Vakfı'nda 10,85'tir. İçerik başına ortalama yorum sayısı ise Sabancı Vakfı'nda 6,01 iken; Vehbi Koç Vakfı'nda 1,58'dir.

\section{İçeriklerin Konularına Yönelik Bulgular}

Vakıflar tarafından yayımlanan Facebook içeriklerinin konu dağılımı Tablo 7'de sunulmuştur. Tablo 7'de sunulan bilgiler 1şığında, Sabancı Vakfı yayımladığ 66 içeriğin 29'unda (\% 43,94) toplumsal cinsiyet eşitliği ve kadına yönelik içeriklere, 9'unda $(\%$ 13,64) özel gün paylaşımı içeriklerine, 5 'inde $(\% 7,58)$ eğitim/burs içeriklerine, 5 'inde $(\% 7,58)$ girişimcilik/ motivasyon/ tasarımcllı içeriklerine, 5 'inde $(\% 7,58)$ engelli yurttaşlara yönelik içeriklere, 4 'ünde $(\%$ 6,06) hayvan hakları ve doğayı korumaya yönelik içeriklere, 3 'ünde $(\% 4,55)$ vakıf tarafından verilen ödüllere yönelik içeriklere, 2'sinde $(\% 3,03)$ kültür ve sanat içeriklerine, 1'inde $(\% 1,51)$ aile içi şiddete karşı çıkmaya yönelik içeriğe, 1'inde $(\% 1,51)$ toplumsal değişime yönelik içeriğe, 1'inde $(\% 1,51)$ anma içeriğine ve 1 'inde $(\% 1,51)$ vakfa verilen ödüllere yönelik içeriğe yer vermiştir. Sabancı Vakfı'nın "sağlık", "kültür, eğitim ve sağlık alanında kalıcı eserler" ve "faaliyet raporu" konu başlıkları altında değerlendirilebilecek herhangi bir paylaşım yapmadığı görülmüştür.

Vehbi Koç Vakfı ise yayımladığ 40 içeriğin 12'sinde (\% 30,00) kültür sanat içeriklerine, 9'unda (\% 22,50) özel gün paylaşımı içeriklerine, 5'inde (\% 12,50) eğitim/burs içeriklerine, 3'ünde (\% $7,50)$ toplumsal cinsiyet eşitliği ve kadına yönelik içeriklere, 3'ünde $(\% 7,50)$ sağlık içeriklerine, 3 'ünde $(\% 7,50)$ kültür, eğitim ve sağlık alanında kalıcı eserlere yönelik içeriklere, 2'sinde (\% $5,00)$ girişimcilik/motivasyon/tasarımcilık içeriklerine, 1'inde (\% 2,50) toplumsal değişime 
yönelik içeriğe, 1'inde (\% 2,50) anma içeriğine ve 1'inde (\% 2,50) faaliyet raporu içeriğine yer vermiştir. Koç Vakfı'ıın "aile içi şiddete yönelik", "vakıf tarafından verilen ödüller", "vakıfa verilen ödüller", "engelli yurttaşlara yönelik", "hayvan hakları ve doğayı korumaya yönelik" konu başlıkları altında değerlendirilebilecek herhangi bir paylaşım yapmadığı görülmüştür.

Tablo 7. Vakıflar Tarafından Yayımlanan Facebook İçeriklerinin Konu Dağılımı

\begin{tabular}{|l|c|c|c|c|}
\hline \multirow{2}{*}{ İçerik Konusu } & \multicolumn{2}{|c|}{ Sabancı Vakfı } & \multicolumn{2}{c|}{ Vehbi Koç Vakfı } \\
\cline { 2 - 5 } & Sayı & $\%$ & Sayı & $\%$ \\
\hline Kültür ve sanat & 2 & $\% 3,03$ & 12 & $\% 30,00$ \\
\hline Eğitim/burs & 5 & $\% 7,58$ & 5 & $\% 12,50$ \\
\hline Toplumsal cinsiyet eşitliği ve kadına yönelik & 29 & $\% 43,94$ & 3 & $\% 7,50$ \\
\hline Aile içi şiddete karşı çıkmaya yönelik & 1 & $\% 1,51$ & - & $\% 0,00$ \\
\hline Toplumsal değişim & 1 & $\% 1,51$ & 1 & $\% 2,50$ \\
\hline Özel gün paylaşımları & 9 & $\% 13,64$ & 9 & $\% 22,50$ \\
\hline Girişimcilik/Motivasyon/Tasarımcılık & 5 & $\% 7,58$ & 2 & $\% 5,00$ \\
\hline Sağlık & - & $\% 0,00$ & 3 & $\% 7,50$ \\
\hline Anma & 1 & $\% 1,51$ & 1 & $\% 2,50$ \\
\hline Vakıf tarafından verilen ödüller & 3 & $\% 4,55$ & - & $\% 0,00$ \\
\hline Vakıfa verilen ödüller & 1 & $\% 1,51$ & - & $\% 0,00$ \\
\hline Engelli yurttaşlara yönelik & 5 & $\% 7,58$ & - & $\% 0,00$ \\
\hline Kültür, eğitim ve sağlık alanında kalıcı eserler & - & $\% 0,00$ & 3 & $\% 7,50$ \\
\hline Hayvan hakları ve doğayı korumaya yönelik & 4 & $\% 6,06$ & - & $\% 0,00$ \\
\hline Faaliyet raporu & - & $\% 0,00$ & 1 & $\% 2,50$ \\
\hline Toplam & $\mathbf{6 6}$ & $\mathbf{9 1 0 0 , 0 0}$ & $\mathbf{4 0}$ & $\mathbf{\% 1 0 0 , 0 0}$ \\
\hline
\end{tabular}

\section{İçeriklerin Türüne Yönelik Bulgular}

Vakıflar tarafından yayımlanan Facebook içeriklerinin türlerine göre dağılımı Tablo 8'de sunulmuştur. Tablo 8'de belirtildiği üzere, Sabancı Vakfı tarafından yayımlanan 66 içeriğin 37'si $(\% 56,06)$ fotoğraf, $29^{\prime}$ u $(\% 43,94)$ videodur. Yayımlanan videoların toplam süresi 22 dakika 1 saniyedir ve 3 milyon 958 bin 949 kez izlenmiştir. Vehbi Koç Vakfı tarafından yayımlanan 40 içeriğin 31'i $(\% 77,50)$ fotoğraf, 9'u $(\% 22,50)$ videodur. Yayımlanan videoların toplam süresi 4 dakika 23 saniyedir ve bin 785 kez izlenmiştir.

Tablo 8. Vakıflar tarafından yayımlanan Facebook içeriklerinin türlerine göre dağılımı

\begin{tabular}{|l|c|c|c|c|}
\hline \multirow{2}{*}{ İçerik Türü } & \multicolumn{2}{|c|}{ Sabancı Vakfı } & \multicolumn{2}{c|}{ Vehbi Koç Vakfı } \\
\cline { 2 - 5 } & Sayı & $\%$ & Sayı & $\%$ \\
\hline Fotoğraf & 37 & $\% 56,06$ & 31 & $\% 77,50$ \\
\hline Video & 29 & $\% 43,94$ & 9 & $\% 22,50$ \\
\hline Toplam & $\mathbf{6 6}$ & $\mathbf{\% 1 0 0 , 0 0}$ & $\mathbf{4 0}$ & $\mathbf{\% 1 0 0 , 0 0}$ \\
\hline
\end{tabular}


Sabancı Vakfı 66 içeriğin 30'unda (\%45,45), Vehbi Koç Vakfı ise 40 içeriğin 7'sinde $(\% 17,50)$ içerikle ilgili daha detaylı bilgiye ulaşmak için internet bağlantı adresi vermiştir. Sabancı Vakfı 66 içeriğin 65'inde $(\% 98,48)$ toplam 302 Facebook içi etiketleme (\#) yapmıştır. Koç Holding ise 40 içeriğin 16 'sında $(\% 40,00)$ toplam 22 Facebook içi etiketleme yapmıştır.

\section{SONUÇ ve DEĞERLENDİRME}

Sabancı Vakfı'nın icra ettiği sosyal sorumluluk projelerinde Birleşmiş Milletler Kalkınma Programı (United Nations Development Programme-UNDP), Birleşmiş Milletler Toplumsal Cinsiyet Eşitliği ve Kadının Güçlenmesi Birimi (UN Agency for Gender Equality \& Women's Empowerment-UN Women), Birleşmiş Milletler Nüfus Fonu (United Nations Population FundUNPFA), Avrupa Vakıflar Merkezi (European Foundation Center-EFC), Engellilerin İnsan Hakları Avrupa Vakuflar Konsorsiyumu (European Consortium of Foundations On Human Rights And Disability), Kızlar Gelin Değil (Girls Not Brides), Clinton Küresel Girişimi (Clinton Global Initiative), Synergos Küresel Filantropistler Ağ1 (Synergos Global Philanthropists Circle), Harvard Üniversitesi, Sabancı Üniversitesi, Aile ve Sosyal Politikalar Bakanlığı, İçişleri Bakanlığı, Milli Eğitim Bakanlığı, Kültür ve Turizm Bakanlığı, Türkiye Belediyeler Birliği, Vehbi Koç Vakfı, Aydın Doğan Vakfı, Enka Vakfı, Mehmet Zorlu Vakfı, Anne Çocuk Eğitim Vakfı (AÇEV), Tohum Otizm Vakfı, Türkiye Teknoloji Geliştirme Vakfı, Başka Bir Okul Mümkün Değil Derneği, Köy Okulları Değişim Ağı Derneği, Yüksekova Kadınları Toplumsal Destekleme ve Kültür Derneği, Nirengi Derneği, Madenci Kadınlar Dayanışma ve Sosyal Yardımlaşma Derneği, Türkiye İşitme Engelliler Derneği, Metropolis Sevenler Derneği (MESEDER) ve Eğitim Reformu Girişimi gibi kuruluşlarla işbirliği içinde bulunduğu görülmektedir.

Vehbi Koç Vakfi'nın icra ettiği sosyal sorumluluk projelerinde Birleşmiş Milletler Gelişim Programı (United Nations Development Programme-UNDP), Birleşmiş Milletler Mülteciler Yüksek Komiserliği (United Nations High Commissioner for Refugees-UNHCR), Avrupa Vakıflar Merkezi (European Foundation Center-EFC), Orta ve Doğu Avrupa'da sivil toplumun ve filantropinin gelişimini teşvik eden Grantmakers East Forum (GEF), Ashoka Sosyal Girişimcilik Programı (Ashoka Social Entrepreneurship Programme), Mozaik Vakfı (Mozaik Foundation), Birleşik Krallık Sosyal Girişimcilik Ağı (Social Enterprise UK), Harvard Üniversitesi, Boğaziçi Üniversitesi, Orta Doğu Teknik Üniversitesi, Ankara Üniversitesi, Galatasaray Üniversitesi, Kocaeli Üniversitesi, Adıyaman Üniversitesi, Celal Bayar Üniversitesi, Koç Üniversitesi, TED Üniversitesi, Abdullah Gül Üniversitesi, Orman Bakanlığı, Milli Eğitim Bakanlığı, Sağlık Bakanlığı, Kültür ve Turizm Bakanlığı, Türkiye Odalar ve Borsalar Birliği, Yapı Kredi Bankası, Kızılay, Tema Vakfı, Türkiye Eğitim Gönüllüleri Vakfı (TEGV), Sabancı Vakfı, Aydın Doğan Vakfı, Enka Vakfı, Mehmet Zorlu Vakfı, Anne Çocuk Eğitim Vakfı (AÇEV), Alternatif Yaşam Derneği, Sosyal İnovasyon İnisiyatifi Derneği, Sürdürülebilir Kalkınma İçin Yenilikçi Çözümler Derneği, Akdeniz Koruma Derneği, Özel Sektör Gönüllüler Derneği (ÖSGD), Olumlu Davranış Geliştirme Derneği (ODGEDER), Ankara Kalkınma Ajansı, Doğu Kalkınma Ajansı, İpekyolu Kalkınma Ajansı, Orta Karadeniz Kalkınma Ajansı ve Eğitim Reformu Girişimi gibi kuruluşlarla işbirliği içinde bulunduğu görülmektedir.

Yukarıda bahsedilen işbirlikleriyle, projeler daha güçlü bir şekilde yapılandırılmış ve uygulanabilirliği arttırılmıştır. Her iki vakfın işbirliği içinde bulunduğu yapıların uluslararası kuruluşlar, devlet kuruluşları, özel sektör kuruluşları, kendileri gibi vakıf ve dernek statüsünde bulunan kuruluşlar olması nedeniyle; Sabancı Vakfı ve Vehbi Koç Vakfı'nın icra ettikleri sosyal sorumluluk faaliyetlerinde toplumun büyük bir kesimine ulaşmayı hedefledikleri sonucuna ulaşılabilmektedir. 
Her iki vakıf da içinde yer aldığı sosyal sorumluluk faaliyetlerinde merkezilik, belirlilik, proaktiflik, gönüllülük ve görünürlük stratejilerini başarı ile uygulayarak bağlı bulundukları holdingler için tanımlanabilir ve ölçümlenebilir ekonomik değer de yaratmıştır. Carroll'un sosyal sorumluluk piramidinde bahsettiği ekonomik, yasal, etik ve gönüllülük sorumlulukları bağlamında değerlendirildiğinde; her iki vakfın da söz konusu dört sorumluluk ilkesini etkili bir şekilde uygulamaya soktuğu değerlendirilebilir.

Koç Holding ve Sabancı Holding sosyal sorumluluk alanında fark yaratabilmek maksadiyla kurmuş oldukları vakıfların web sitelerinde ve Facebook hesaplarında kültür ve sanat; eğitim; burs; toplumsal cinsiyet eşitliği; kadın hakları; aile içi şiddete karşı farkındalık yaratma; özel gün kutlamaları; sağlık; anma; engelli yurttaşlara yönelik farkındalığı arttırma; kültür, eğitim ve sağlık alanında topluma sundukları kalıcı eserler; hayvan hakları ve doğanın korunmasına yönelik bilinç geliştirme, verdikleri ödüller ve aldıkları ödüller gibi konularda içerik sunmaktadırlar.

Vakıfla ilgili genel bilgileri açıklama, vakıfla ilgili bilgilerin paylaşımı ve üyelerle bağ kurma kategorilerinden oluşan web sitesi analizinde; iki vakfın da iletişim performansının tatmin edici seviyede olduğu değerlendirilmiş ve iki vakıf arasında dikkate değer bir farklılığın bulunmadığı sonucuna ulaşılmıştır. Bununla birlikte, her iki vakfın web sitesinde de oturum açma bağlantısı bulunmaması, vakıfların sosyal medya hesaplarını etkin bir şekilde kullanmasının bir sonucu olarak düşünülebilir.

1 Mart 2021 - 1 Haziran 2021 tarihleri arasını kapsayan Facebook analizi; içeriklerin sayısal değerleri, konuları ve türleri olmak üzere üç başlık altında yapılmıştır. Söz konusu zaman aralığında, Sabancı Vakfı'nın Facebook'ta yayımladığı içerik sayısı, Vehbi Koç Vakfı'nın yayımladığı içerik sayısının 1,65 katıdır. Sabancı Vakfı'nın yayımladığı içeriklerin beğenilme sayısı, Vehbi Koç Vakfı'nın yayımladığı içeriklerin beğenilme sayısının 6,42 katıdır. Sabancı Vakfı'nın yayımladığı içeriklerin Facebook kullanıcıları tarafından paylaşım sayısı, Vehbi Koç Vakfı'nın yayımladığı içeriklerin Facebook kullanıcıları tarafından paylaşım sayısının 5,04 katıdır. Sabancı Vakfı tarafından yayımlanan içeriklere yapılan yorum sayısı, Vehbi Koç Vakfı tarafından yayımlanan içeriklere yapılan yorum sayısının 6,30 katıdır. Yukarıda da belirtildiği gibi Sabancı Vakfı Vehbi Koç Vakfı'ndan daha fazla Facebook içeriği yayımlamıştır. Bu kapsamda; beğeni, paylaşım ve yorum sayılarında daha hassas bir çıkarımda bulunabilmek için, söz konusu sayıların içerik başına ortalamaları da hesaplanmıştır. Sabancı Vakfı'nın içerik başına ortalama beğeni sayısı, Vehbi Koç Vakfı'nın içerik başına ortalama beğeni sayısının 3,89 katıdır. Sabancı Vakfı'nın içerik başına ortalama paylaşım sayısı, Vehbi Koç Vakfı'nın içerik başına ortalama paylaşım sayısını 3,05 katıdır. Sabancı Vakfı'nın içerik başına ortalama yorum sayısı, Vehbi Koç Vakfı'nın içerik başına ortalama yorum sayısının 3,80 katıdır. Gelinen noktada, Sabancı Vakfı'nın sayısal değerler bağlamında Facebook'u Vehbi Koç Vakfı'ndan daha etkin bir şekilde kullanıldığı sonucuna ulaşılabilmektedir.

Söz konusu zaman diliminde, Sabancı Vakfı ve Vehbi Koç Vakfı'nın "eğitim/burs", "toplumsal değişim", "özel gün", "girişimcilik/motivasyon/tasarımcılık", "toplumsal cinsiyet eşitliği ve kadına yönelik" Facebook paylaşımlarının benzer oranlarda olduğu görülmektedir. Sabancı Vakfı "sağlık", "kültür, eğitim ve sağlık alanında kalıcı eserler" ve "faaliyet raporu" konularında herhangi bir paylaşım yapmamıştır. Vehbi Koç Vakfı ise "aile içi şiddete karşı çıkma", "vakıf tarafından verilen ödüller", "vakıfa verilen ödüller", "engelli yurttaşlara yönelik farkındalık" ve "hayvan hakları ve doğayı korumaya yönelik farkındalık" konularında herhangi bir paylaşım yapmamıştır. Vakıf tarafından verilen ya da vakıfa verilen ödüller hakkında Vehbi Koç Vakfı tarafından paylaşım yapılmaması, Vehbi Koç Vakfı'nın bu konuyu ihmal ettiği şeklinde 
yorumlanmamalıdır. Yapılan incelemede Vehbi Koç Vakfı'nın içerik analizi dışında kalan farklı zaman dilimlerde bu konu üzerine içerik paylaştığı görülmüştür. Sabancı Vakfı söz konusu dönemde engelli yurttaşlara yönelik 5 , hayvan hakları ve doğayı korumaya yönelik 4 , aile içi şiddete karşı çıkmaya yönelik 1 paylaşım yaparken; Vehbi Koç Vakfı'nın bu üç konu bağlamında herhangi bir paylaşım yapmadığı görülmüştür. Bu, oldukça dikkate değer ve Vehbi Koç Vakfı özelinde eleştiriye açık bir durumdur. Çünkü söz konusu üç konu da zaman aralığı ile bağlantılı olmayan, kuruluşların sürekli ve kesintisiz bir şekilde üzerinde durması gereken toplumsal sorumluluk konularıdır. Vehbi Koç Vakfi'nın "kültür ve sanat" alanında yaptığı 12 paylaşım, Sabancı Vakfı'nın yaptığı 2 paylaşımın oldukça üzerindedir. Buradan hareketle, Vehbi Koç Vakfı'nın yaptığı paylaşımlarda kültürel ve sanatsal faaliyetlere Sabancı Vakfı'ndan çok daha fazla öncelik verdiği değerlendirilebilir. Sabancı Vakfı "toplumsal cinsiyet eşitliği ve kadına yönelik farkındalık" konusunda üç aylık dönemde 29 içerik yayınlarken, Koç Holding 3 içerikte kalmıştır. 8 Mart Dünya Emekçi Kadınlar Günü'nün içerik analizinin yapıldığı tarihler arasında kalmasının bu duruma etkisi olduğu değerlendirilebilir. Bununla birlikte, Sabancı Holding Yönetim Kurulu Başkanı Güler Sabancı tarafından toplumsal cinsiyet eşitliği ve kadına yapılan vurgunun, Sabancı Vakfı'nın bu konu üzerinde daha fazla durmasına sebep olduğu düşünülebilir.

Sabancı Vakfı tarafından yayımlanan içeriklerde fotoğraf ve videoların birbirine yakın oranda kullanıldığı görülmektedir. Vehbi Koç Vakfı içeriklerinde ise fotoğrafın daha fazla tercih edildiği görülmektedir. Kullanılan fotoğraf sayısı, video sayısının 3,44 katıdır. Sabancı Vakfı tarafından kullanılan videoların süresi, Vehbi Koç Vakfı tarafından kullanılan videoların süresinin 5,23 katıdır. Bununla birlikte, Sabancı Vakfı tarafından yayımlanan videoların izlenme sayısı, Vehbi Koç Vakfı tarafından yayımlanan videoların izlenme sayısının 2217,89 katıdır.

Sabancı Vakfı yayımladığı Facebook içeriklerini internet bağlantı adresleriyle, Vehbi Koç Vakfı'ndan 2,60 kat daha fazla desteklemektedir. Ayrıca, Sabancı Vakfı Facebook içeriklerini, Vehbi Koç Vakfi'ndan 2,46 kat daha fazla etiketlemektedir.

İletişim teknolojilerindeki ilerlemeler ile birlikte, web siteleri ve sosyal medya platformları en önemli halkla ilişkiler araçları haline gelmiştir. Başarılı bir halkla ilişkiler politikası, izleyiciler ile sürekli ve kesintisiz etkileşim kurularak yürütülebilir. Bu bağlamda uluslararası faaliyet gösteren büyük şirketler ve kurumlar, izleyicilerinin talepleri hakkında ve bilgi almak için yazdıkları yorumlarını sürekli olarak cevaplamaktadır. Yapılan analizde gerek Koç Vakfı'nın gerekse Sabancı Vakfı'nın izleyicilerin yaptıkları yorumlara cevap vermede yetersiz kaldıkları sonucuna ulaşılmıştır.

Sonuç olarak, Sabancı Vakfı ve Vehbi Koç Vakfı ülkemizde sosyal sorumluluk kavramına vurgu yapan başat aktörlerin başında gelen kuruluşlardır. Her iki kurum da dijital alanda başarılı bir şekilde sosyal sorumluluk faaliyetlerini yürütmektedirler. Sabancı Vakfı ve Vehbi Koç Vakfı'nın web siteleri kullanımı sosyal sorumluluk bağlamında birbirlerine benzerlik gösterse de; Sabancı Vakfı Facebook sosyal medya hesabını, Vehbi Koç Vakfı'na kıyasla daha etkin bir biçimde kullanmaktadır. Bununla birlikte, vakıfların kullanıcıların sosyal medya hesaplarında daha fazla vakit geçirmelerini sağlayacak anket ve ödüllü oyunlar gibi aktiviteler düzenlemesinin sosyal sorumluluk faaliyetlerinde kendilerine bir avantaj sağlayabileceği değerlendirilebilir. Söz konusu aktivitelerle izleyicilerden daha fazla geri bildirim almaları ve izleyicilerin içerikleri daha fazla paylaşmaları sağlanabilir. Bu sayede, vakıfların görünürlüklerinin artması da mümkün olabilir. 


\section{KAYNAKLAR}

Acquaah, M. (2003). Organizational Competence and Firm-Specific Tobin's Q: The Moderating Role of Corporate Reputation, Strategic Organization, 1(4): 383-411.

Backman, J. (1975). Social Responsibility and Accountability. New York: New York University Press.

Bakan, İ., Erşahan B., Büyükbeşe T. ve Soğancı G. (2019). Örgütsel Ustalığın Kurumsal İmaj ve Kurumsal İtibar Üzerindeki Etkisi: Bir Alan Araştırması, Yönetim ve Ekonomi Araştırmaları Dergisi, 17(2): 193-213.

Budak, G. ve Budak, G. (2014). İmaj Mühendisliği Vizyonundan Halkla İlişkiler. İzmir: Barış Yayınları.

Burke, L. and Logsdon, J. M. (1996). How Corporate Social Responsibility Pays Off, Long Range Planning, 29(4): 495-502.

Carroll, A. B. (1991). The Pyramid of Corporate Social Responsibility: Toward the Moral Management of Organizational Stakeholders, Business Horizons, 34(4): 39-48.

Carroll, A. B. (1999). Corporate Social Responsibility Evolution of a Definitional Construct, Business \& Society, 38(3): 268-295.

Chahal, H. and Sharma, R. D. (2006). Implications of Corporate Social Responsibility on Marketing Performance: A Conceptual Framework, Journal of Services Research, 6(1): 205-216.

Clark, C. E. (2000). Differences between Public Relations and Corporate Social Responsibility: An Analysis, Public Relations Review, 26(3): 363-380.

Creyer, E. H. (1997). The Influence of Firm Behavior on Purchase Intention: Do Consumers Really Care About Business Ethics?, Journal of Consumer Marketing, 14(6): 421-432.

Çelik, Y. ve Aydın, Ö. K. (2016). Reklamların İdari Denetimi: Televizyon Reklamlarına İlişkin Reklam Kurulu Kararlarının Analizi, Gümüşhane Üniversitesi İletişim Fakültesi Elektronik Dergisi, 4(1): 220-252.

Dacin, M. T. (1997). Isomorphism in Context: The Power and Prescription of Institutional Norms, Academy of Management Journal, 40(1): 46-81.

Davis, K. and Blomstrom, R. L. (1966). Business and Its Environment. St. Louis: McGraw-Hill Book Company.

Fombrun, C. J. (1996). Reputation: Realizing Value from the Corporate Image. Boston: Harvard Business School Press.

Fombrun, C. J. (2000). The Value to Be Found in Corporate Reputation, Financial Times.

Fombrun, C. J. (2001). Corporate Reputations as Economic Assets. In M. Hitt, R. Freeman and J. Harrison (Eds.), The Blackwell Handbook of Strategic Management (pp. 289-312). Malden, MA: Blackwell.

Fombrun, C. J. and Shanley, M. (1990). What's In a Name? Reputation Building and Corporate Strategy, Academy of Management Journal, 33(2): 233-258.

Garriga, E. and Melé, D. (2004). Corporate Social Responsibility Theories: Mapping the Territory, Journal of Business Ethics, 53(1-2): 51-71. 
Geray, H. (2006). Toplumsal Araştırmalarda Nicel ve Nitel Yöntemlere Giriş. Ankara: Siyasal Kitabevi.

Greenberg, J. and MacAulay, M. (2009). Npo 2.0? Exploring the Web Presence of Environmental Nonprofit Organizations in Canada, Global Media Journal-Canadian Edition, 2(1): 63-88.

Handelman, J. M. and Arnold, S. J. (1999). The Role of Marketing Actions with a Social Dimension: Appeals to the Institutional Environment, The Journal of Marketing, 63: 33-48.

Karaköse, T. (2007). Kurumların DNA'sı İtibar ve Yönetimi. Ankara: Nobel Yayın-Dağııım.

Karatepe, S. (2008). İtibar Yönetimi: Halkla İlişkilerde Güven Yaratma, Elektronik Sosyal Bilimler Dergisi, 7(23): 77-97.

Kitchen, P. J. and Watson, T. (2010). Reputation Management: Corporate Image and Communication. [Online] http://eprints.bournemouth.ac.uk/12633/2/Chapter_13_def.pdf [Erişim Tarihi: 30 Mayıs 2021].

Lloyd, S. (2007): Corporate Reputation: Ontology and Measurement, Doctoral dissertation, AUT University Business School, New Zealand.

McGuire, J. W. (1963). Business and Society. St. Louis: McGraw-Hill Book Company.

Meyer, J. W. and Scott, W. R. (1992), Introduction. In J. W. Meyer and W. R. Scott (Eds.), Organizational Environments: Ritual and Rationality (pp. 1-5). Beverly Hills, CA: Sage Publications.

Nourick, S. (2001). Corporate Social Responsibility: Partners for Progress. Organization for Economic Cooperation and Development (OECD) Publishing, Paris.

Ogrizek, M. (2002). The Effect of Corporate Social Responsibility on the Branding of Financial Services, Journal of Financial Services Marketing, 6(3): 215-228.

Polat, S. (2009) Yükseköğretim Örgütlerinde Örgütsel İmaj Yönetimi: Örgütsel İmajin Öncülleri ve Çıktıları. [Online] http://www.eab.org.tr/eab/2009/pdf/106.pdf [Erişim Tarihi: 30 Mayıs 2021].

Robin, D. P. and Reidenbach, R. E. (1987). Social Responsibility, Ethics, and Marketing Strategy: Closing the Gap between Concept and Application, The Journal of Marketing, 51(1): 44-58.

Tanimoto, K. (2004). Changes in the Market Society and Corporate Social Responsibility, Asian Business \& Management, 3(2): 151-172.

Votaw, D. (1972). Genius Becomes Rare: A Comment on the Doctrine of Social Responsibility Pt. I, California Management Review, 15(2): 25-31.

Yılmazel, M. (2011). Türkiye'de Faaliyet Gösteren Vakıfların Sosyal Medya Kullanımlarına Yönelik Bir İçerik Analizi, Yüksek Lisans Tezi, Anadolu Üniversitesi Sosyal Bilimler Enstitüsü, Eskişehir.

Yirmibeş, S. (2010). Kurumsal İtibar Yönetimi ve Kamuya Bağ̆ Bir Kurumda Kurumsal İtibarın Ölçülmesi Üzerine Bir Araştırma, Yüksek Lisans Tezi, Dokuz Eylül Üniversitesi Sosyal Bilimler Enstitüsü, İzmir. 